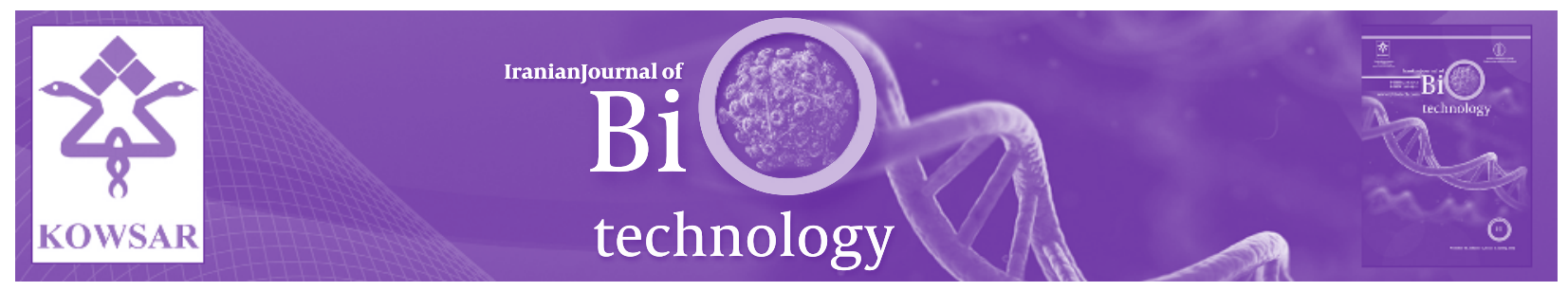

\title{
Characterization of Coat Protein Gene of Cucumber Mosaic Virus Isolates in Iran
}

\author{
Nazanin Arafati ${ }^{1}$, Shirin Farzadfar ${ }^{2, *}$, Reza Pourrahim ${ }^{2}$ \\ ${ }^{1}$ Department of Agronomy and Plant Breeding, Sabzevar Branch Islamic Azad University, Sabzevar, IR Iran \\ ${ }^{2}$ Department of Plant Virus Research, Iranian Research Institute of Plant Protection, Tehran, IR Iran \\ *Corresponding author: Shirin Farzadfar, Department of Plant Virus Research, Iranian Research Institute of Plant Protection, P.O.Box 19395-1454, Tehran, IR \\ Iran. Tel: +98-2122403014., Fax: +98-2122402570, E-mail: farzadfar2002@yahoo.com.
}

\section{A B S T R A C T}

Background: Cucumber mosaic virus (CMV) from the Bromoviridae family, is one of the most widespread plant viruses in the world.

objectives: In the present study tomato fields in Guilan, Isfahan, Khorasan Razavi, Khuzestan and Tehran provinces were surveyed to determine the presence of CMV subgroups during 2011-2012.

Materials and Methods: Out of 305 symptomatic leaf samples tested by Enzyme-linked immuno sorbent assay (ELISA), 147 samples (48.2 \%) were found to be infected by CMV with the highest percentage in Khorasan Razavi (67.4\%) followed by Khuzestan (50.6\%), Tehran (48\%), Isfahan (38.2\%) and Guilan (34.3\%). The coat protein (CP) gene in the 19 sequenced CMV isolates composed of 657 nucleotides (nt) in a size that encodes 218 amino acids. Phylogenetic analysis based on the nt CP gene showed that the ToKz1, ToKz2, ToKz3 and ToKz4 from Khuzestan fell into subgroup IB and the rest of the Iranian isolates including those sequenced in this study fell into subgroup IA.

Results: Subsequent analyses showed that the Iranian CMV isolates belonging to subgroup IA of CMV were most related phylogenetically to each other and they were distinct from the subgroup IB and subgroup II isolates. Bioassay on Nicotiana glutinosa and Solanum lycopersicum showed that the symptoms caused by subgroup IB isolates from Khuzestan were milder than those caused by CMV isolates from subgroup IA under this study.

Conclusions: In Iran only subgroups IA and II have been reported, however for the first time this study shows the occurrence and phylogenetic relationships of CMV subgroup IB isolated from tomato fields in West Asia, Iran.

Keywords: Cucumber Mosaic Virus; Iran; Subgroup IB; Phylogeny

Copyright (c) 2013, National Institute of Genetic Engineering and Biotechnology; Published by Kowsar Corp.

\section{Background}

Cucumber mosaic virus (CMV) from the genus Cucumovirus, family Bromoviridae has great economic importance because it affects a wide range of hosts, including over 1300 species in more than 500 genera, over 100 families, with new hosts being reported each year (1). The genome

of CMV consists of three single-stranded positive-sense RNAs. RNA1 and RNA2 encode 1a and 2a proteins respectively, essential for replication. A small protein (2b) associated with the suppression of RNA interference is also encoded by RNA2. RNA3 is dicistronic and encodes

Article type: Brief Report; Received: 06 Nov 2012; Revised: 26 Nov 2012; Accepted: 13 Jan 2013; Epub: 12 May 2013, Ppub: June 2013

Implication for health policy/practice/research/medical education:

This study has implication on plant pathology research.

PPlease cite this paper as:

Arafati N, Farzadfar S, Pourrahim R. Characterization of Coat Protein Gene of Cucumber Mosaic Virus Isolates in Iran. Iran J Biotech. 2013: 11(2): 109-14. DOI: 10.5812/ijb.10715

Copyright (C) 2013, National Institute of Genetic Engineering and Biotechnology; Published by Kowsar Corp.

This is an Open Access article distributed under the terms of the Creative Commons Attribution License (http://creativecommons.org/licenses/by/3.0), which permits unrestricted use, distribution, and reproduction in any medium, provided the original work is properly cited. 
the movement protein (MP) and coat protein (CP). The second ORF encodes the $24 \mathrm{kDa} \mathrm{CP}$, which is expressed through a sub-genomic RNA4 (2) and is involved in encapsidation, systemic infection or long distance movement within infected plants, host range and aphid transmission (3). Several of CMV isolates have been previously described and classified into two subgroups, I and II, according to serological relationships, peptide mapping of the $\mathrm{CP}$, nucleic acid hybridization and nucleotide sequence identity $(3,4)$. Most CMV isolates belong to subgroup I (5) and later phylogenetic analysis has led to a further subdivision of this subgroup into subgroups IA and IB (6). Subgroup II isolates are found more frequently in cooler areas of temperate regions. Most isolates in subgroup IB are reported from East Asia, which has been proposed to be the origin of this subgroup (7) although some have also been reported from other areas, i.e. the Mediterranean region, California, Brazil, Australia and Greece. Those in the Mediterranean could have been introduced recently from East Asia (1, 7). Isolates of subgroups I and II can be identified using monoclonal antibodies, and isolates from subgroups IA, IB and II can be determined by reverse transcriptase polymerase chain reaction (RT-PCR) (8). Many studies on CMV in Iran have been limited to serological and biological detection. Recently analysis of the complete CP gene of Iranian CMV isolates from North West revealed that both subgroup I and II variants occur, however, with a higher incidence of subgroup I variants (9-13).

\section{Objectives}

In the present study tomato fields in Guilan, Isfahan, Khorasan Razavi, Khuzestan and Tehran provinces were surveyed to determine the presence of CMV subgroups during 2011-2012.

\section{Materials and Methods}

During the growing seasons of 2011 - 2012, surveys were conducted in the main tomato growing areas in Guilan, Isfahan, Khorasan-e-Razavi, Khuzestan and Tehran provinces to determine the CMV subgroups (Table 1). A total number of 305 leaf samples with virus like symptoms including chlorotic local lesions, fern leaf/shoestring, mottle, mosaic, vein necrosis and yellows were collected. These samples were tested for CMV infection by double antibody sandwich (DAS)-ELISA, as described by Clark and Adams (14) using CMV specific polyclonal antibodies (CMV-IgG) purchased from Bioreba (Reinach, Switzerland). According to the ELISA results, 147 (48.2 $\%$ ) out of 305 symptomatic leaf samples, were found to be infected by CMV with the highest percentage in Khorasan Razavi (67.4\%) followed by Khuseztan (50.6\%), Tehran (48\%), Isfahan (38.2\%) and Guilan (34.3\%). Sixty out of 147 ELISA-positive samples were homogenized in $0.1 \mathrm{M} \mathrm{K}$ - phosphate buffer ( $\mathrm{pH}$ 7.4) and mechanically inoculated onto Nicotiana tabacum cv. Samsun plants dusted with carborundum. Each virus isolate was biologically purified through a single local isolation that was repeated three times on Chenopodium quinoa and subsequently propagated in N. tabacum cv. Samsun. Host range was then examined using seven species belonging to Chenopodiaceae, Cucurbitaceae, Fabaceae and Solanaceae families.

\section{Results}

The CMV isolates induced similar symptoms on indicator plants belonging to the families Cucurbitaceae, Fabaceae and Chenopodiaceae. However, on Solanaceae indicator plants, the CMV isolates from Khuzestan could be differentiated from other isolates by expressing milder symptoms on N. glutinosa (Figure $1 A$ and $1 B$ ) and S. lycopersicum (Figure 1C and 1D). Total RNA was extracted from 25 CMV-infected $N$. tabacum cv. Samsun using Tri-reagent (Sigma) and first-strand cDNA synthesis was performed using RevertAid M-MuLV reverse transcriptase according to the manufacturer's instructions (Fermentas UAB, Lithuania). First, CMV isolates were tested for the presence of satellite RNA and their classification in different subgroups was determined using specific primers as described previously (8). A DNA fragment with the expected size (about $600 \mathrm{bp}$ ) was amplified in all CMV isolates using subgroup I specific primers whereas no amplicon was obtained for CMV subgroup II or satellite RNA. Subsequent RT-PCR reactions were performed using specific primers designed in the CMV CP gene, (11) and DNA amplicons were sequenced in both directions using the BigDye Terminator v3.1 Cycle Sequencing Ready Reaction Kit and an Applied Biosystems Genetic Analyser DNA model 310 (Applied Biosystems, Foster City, CA, USA). The complete CP gene nucleotide sequence of 19 Iranian CMV isolates was determined and shown to be $657 \mathrm{nt}$ long with an open reading frame (ORF) of 218 amino acids.

The relationships of the aligned genes were calculated separately using the NJ and ML methods. Amino acid sequences corresponding to $\mathrm{CP}$ were aligned using CLUSTAL X2 (15) with TRANSALIGN (kindly supplied by George Weiller, Australian National University, Canberra, Australia) for optimal alignment (16). Recombination events, putative parental isolates of recombinants, and recombination break points were analyzed using several methods implemented in the RDP3 version 3.44b (17) with default configuration and a Bonferroni corrected P-value cut-off of 0.01 and 0.05 . No apparent recombination events $\left(P<1 \times 10^{-6}\right)$ were found in the complete nucleotide sequence of the $\mathrm{CP}$ gene of Iranian isolates. The evolutionary history was inferred using the NJ method implemented in MEGA 4 (18). 


\begin{tabular}{|c|c|c|c|c|c|}
\hline Province/City & Isolate & Subgroup & Host & Accession No. & Reference \\
\hline \multicolumn{6}{|l|}{ Azerbaijan-e-Sharqi } \\
\hline Basmenj & B13 & IA & C.sativus & AY871070 & Bashir et al., 2006 \\
\hline Basmenj & B23 & IA & C. sativus & AY871071 & Bashir et al., 2006 \\
\hline Basmenj & FI3 & IA & Cucurbit sp. & DQ002883 & Bashir et al., 2006 \\
\hline Basmenj & FI2 & IA & Cucurbit sp. & DQ002884 & Bashir et al., 2006 \\
\hline Bonab & GI1 & IA & C. sativus & DQ002885 & Bashir et al., 2006 \\
\hline Shabestar & S337 & IA & C. sativus & AY871069 & Bashir et al., 2006 \\
\hline Shendabad & SH17 & IA & C. sativus & AY871068 & Bashir et al., 2006 \\
\hline Shendabad & DI3 & IA & Cucurbit sp. & DQ002879 & Bashir et al., 2006 \\
\hline Shendabad & DI2 & IA & Cucurbit sp. & DQ002877 & Bashir et al., 2006 \\
\hline Shendabad & DI2 & IA & Cucurbit sp. & DQ002878 & Bashir et al., 2006 \\
\hline Shendabad & DI1 & IA & Cucurbitsp. & DQ002876 & Bashir et al., 2006 \\
\hline Tabriz & FI2 & IA & Cucurbit sp. & DQ002881 & Bashir et al., 2006 \\
\hline Tabriz & EI3 & IA & Cucurbit sp. & DQ002882 & Bashir et al., 2006 \\
\hline Tabriz & EI1 & IA & Cucurbitsp. & DQ002880 & Bashir et al., 2006 \\
\hline \multicolumn{6}{|l|}{ Guilan } \\
\hline Astanehashrafieh & ToG1 & IA & S. lycopersicum & KC122246 & This study \\
\hline Astanehashrafieh & ToG2 & IA & S. lycopersicum & KC122247 & This study \\
\hline Astanehashrafieh & ToG3 & IA & S. lycopersicum & KC122248 & This study \\
\hline Astanehashrafieh & ToG4 & IA & S. lycopersicum & KC122249 & This study \\
\hline \multicolumn{6}{|l|}{ Fars } \\
\hline Shiraz & LD & II & L. draba & EF050074 & Rasoulpour \&Izadpanah 2008 \\
\hline \multicolumn{6}{|l|}{ Isfahan } \\
\hline Isfahan & ToIsf1 & IA & L. esculentum & KC122250 & This study \\
\hline Isfahan & ToIsf2 & IA & L. esculentum & KC122251 & This study \\
\hline Isfahan & ToIsf3 & IA & L. esculentum & KC122252 & This study \\
\hline Isfahan & ToIsf4 & IA & L. esculentum & KC122253 & This study \\
\hline Isfahan & $\mathrm{CMV}-\mathrm{Cu}$ & IA & C. sativus & EF620777 & Rasoulpour and Izadpanah 2008 \\
\hline \multicolumn{6}{|l|}{ KhorasanRazavi } \\
\hline Sabzehvar & ToKR1 & IA & L.esculentum & KC122254 & This study \\
\hline Sabzehvar & ToKR2 & IA & L. esculentum & KC122255 & This study \\
\hline Sabzehvar & ToKR3 & IA & L. esculentum & KC122256 & This study \\
\hline Sabzehvar & ToKR4 & IA & L.esculentum & KC122257 & This study \\
\hline \multicolumn{6}{|l|}{ Khuzestan } \\
\hline Safi abad & ToKz1 & IB & L. esculentum & KC122258 & This study \\
\hline Safi abad & ToKz2 & IB & L. esculentum & KC122259 & This study \\
\hline Safi abad & ToKz3 & IB & L. esculentum & KC122260 & This study \\
\hline Safi abad & ToKz4 & IB & L. esculentum & KC122261 & This study \\
\hline \multicolumn{6}{|l|}{ Tehran } \\
\hline Varamin & ToV2 & IA & L. esculentum & JX865603 & This study \\
\hline Varamin & ToV11 & IA & L.esculentum & JX865604 & This study \\
\hline Varamin & ToV29 & IA & L. esculentum & JX865605 & This study \\
\hline \multicolumn{6}{|c|}{ Representative isolates } \\
\hline- & Fny & IA & - & NC_001440 & Owen and Palukaitis, 1998 \\
\hline Greece & G10 & IB & S. lycopersicum & AY541691 & Sclavounos et al., 2006 \\
\hline Greece & G2 & IB & S. lycopersicum & AY450854 & Sclavounos et al., 2006 \\
\hline India & banana & IB & Musa sp. & AY125575 & - \\
\hline India & J\&K & IB & C. citratus & EF153737 & - \\
\hline France & $\begin{array}{l}\text { 22Hua- } \\
\text { hine }\end{array}$ & IB & C. diffusa & FN554693 & Farreyrol et al., 2010 \\
\hline- & Trk7 & II & & L15336 & Salanki et al., 1994 \\
\hline
\end{tabular}




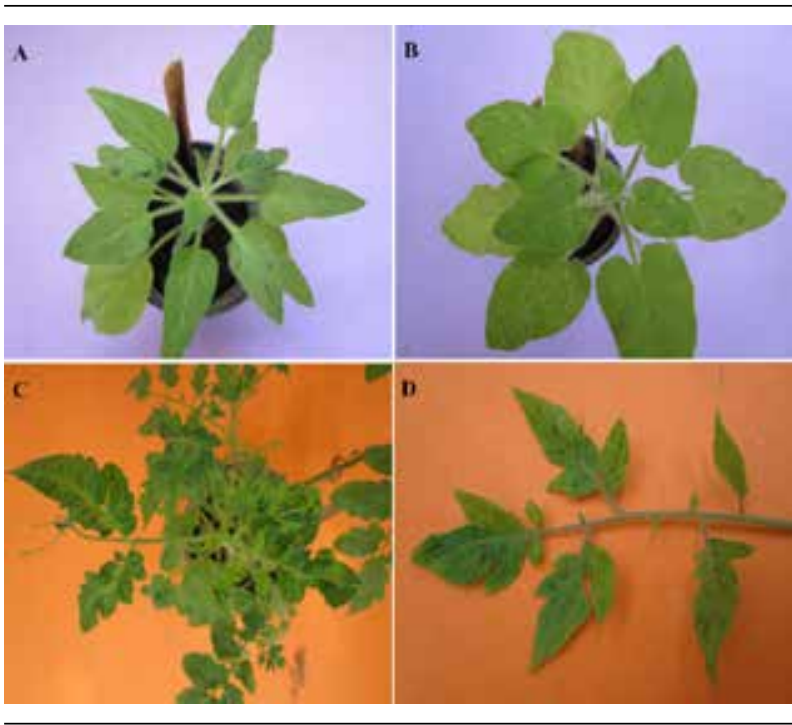

Figure 1. CMV Isolate Subgroup IA induced More Severe Mottle and Leaf Deformations on N. glutinosa (A) and S. lycopersicum (C) than Subgroup IB Isolate From Khuzestan (B and D)

The bootstrap consensus tree inferred from 1000 replicates was taken to represent the evolutionary history of the taxa analyzed. Also, the phylogenetic relationships were determined using maximum-likelihood (ML) tree algorithm of PAUP 4.0 beta Version 8 (19). The calculat- ed trees were displayed by TREEVIEW (20). The Kimura 2-parameter (21) and Dayhoff PAM250 matrices (22) were used to estimate the nucleotide and amino acid distances among the CP gene of 19 CMV Iranian isolates characterized in this study and of Fny isolate (subgroup IA) (23), Banana, J\&K, 22Huahine, G2 and G10 isolates (subgroup IB) (7, 24); and Trk7 (25) from subgroup II (Table 2). Phylogenetic trees constructed by NJ and ML methods using CP genes of the 42 isolates (Table 1) showed three groups, which were strongly supported by bootstrap analyses (Figure 2). Most of the CMV isolates from Isfahan, Khorasan Razavi, Tehran and all of the previously reported CMV isolates from North West of Iran with CMV-Cu (EF620777) fell into subgroup IA. Moreover, our sequenced CMV isolates from Khuzestan (Accession Nos. KC122258-KC122261) fell into subgroup IB (Figure 2). The genetic distances showed that the Iranian CMV isolates in subgroup IB were most related to G10 isolates from Greece with 0.93 and $1.32 \%$ nucleotide and amino acids, respectively. Low genetic distance of 0.46 to $0.61 \%$ was estimated for Iranian subgroup IB isolates (Table 2 ). The genetic distance between Iranian subgroup IA and IB isolates was $0-3.6 \%$ and $0-1.4 \%$, respectively, while the inter-subgroup distance was 7-9.5\%. As expected, Iranian subgroup IA and IB isolates were distantly related to subgroup II isolates $(26.8-28.3 \%$ and $27.9-28.6 \%$, respectively) (table not shown).

Table 2. Comparison of Nucleotide and Amino Acid Distance Between Iranian Cucumber Mosaic Virus Isolates and Other Exotic Isolates Belonging to Subgroup IB a

\begin{tabular}{lllllllllll} 
& ToKz1 & ToKz2 & ToKz3 & ToKz4 & G2 & G10 & Banana & 22 Huahine & Jand K \\
\hline ToKz1 & - & 0.00620 & 0.00620 & 0.00464 & 0.01716 & 0.01559 & 0.04118 & 0.02985 & 0.03311 \\
\hline ToKz2 & 0.00885 & - & 0.00619 & 0.00464 & 0.01087 & 0.01244 & 0.03791 & 0.02663 & 0.02988 \\
\hline ToKz3 & 0.01329 & 0.01320 & - & 0.00464 & 0.01087 & 0.00931 & 0.03469 & 0.02346 & 0.02669 \\
\hline ToKz4 & 0.01328 & 0.00438 & 0.00876 & - & 0.01244 & 0.01400 & 0.03952 & 0.02823 & 0.03148 \\
\hline G2 & 0.01773 & 0.00878 & 0.00437 & 0.00437 & - & 0.00154 & 0.03472 & 0.02348 & 0.02507 \\
\hline G10 & 0.01329 & 0.01320 & 0.00001 & 0.00876 & 0.00437 & - & 0.03311 & 0.02190 & 0.02348 \\
\hline banana & 0.02699 & 0.02681 & 0.01331 & 0.02225 & 0.01775 & 0.01331 & - & 0.02831 & 0.03151 \\
\hline 22Huahine & 0.02244 & 0.02229 & 0.00885 & 0.01775 & 0.01328 & 0.00885 & 0.00440 & - & 0.02991 \\
\hline Jand K & 0.02244 & 0.02228 & 0.00885 & 0.01775 & 0.01328 & 0.00885 & 0.01326 & 0.00882 & - \\
\hline
\end{tabular}

The nucleotide (below diagonal) and amino acid (above diagonal) distances were assessed using Kimura two-parameter (21) and Dayhoff PAM250 matrices (22). The values range between $0(0 \%)$ and $1(100 \%)$ substitutions per nucleotide or amino acid site.

\section{Discussion}

CMV isolates belonging to subgroups IA (13) and II (12) were previously reported in Iran. Our findings show for the first time the occurrence IB subgroup isolates of CMV in tomato fields of Khuzestan, South of Iran. The occurrence of subgroup IB in Iran may be related to the widespread cultivation of newly introduced commercial tomato cultivars and changes in CMV populations in the region. Their presence could have also resulted from the use of infected seeds. Although Iranian isolates belonging to subgroup IB are the first reported members of this subgroup in West Asia, we do not yet know whether these are dominant isolates in this region. 
Figure 2. Phylogeneic Tree Constructed by the NJ Algorithm Implemented in MEGA 4 (18).

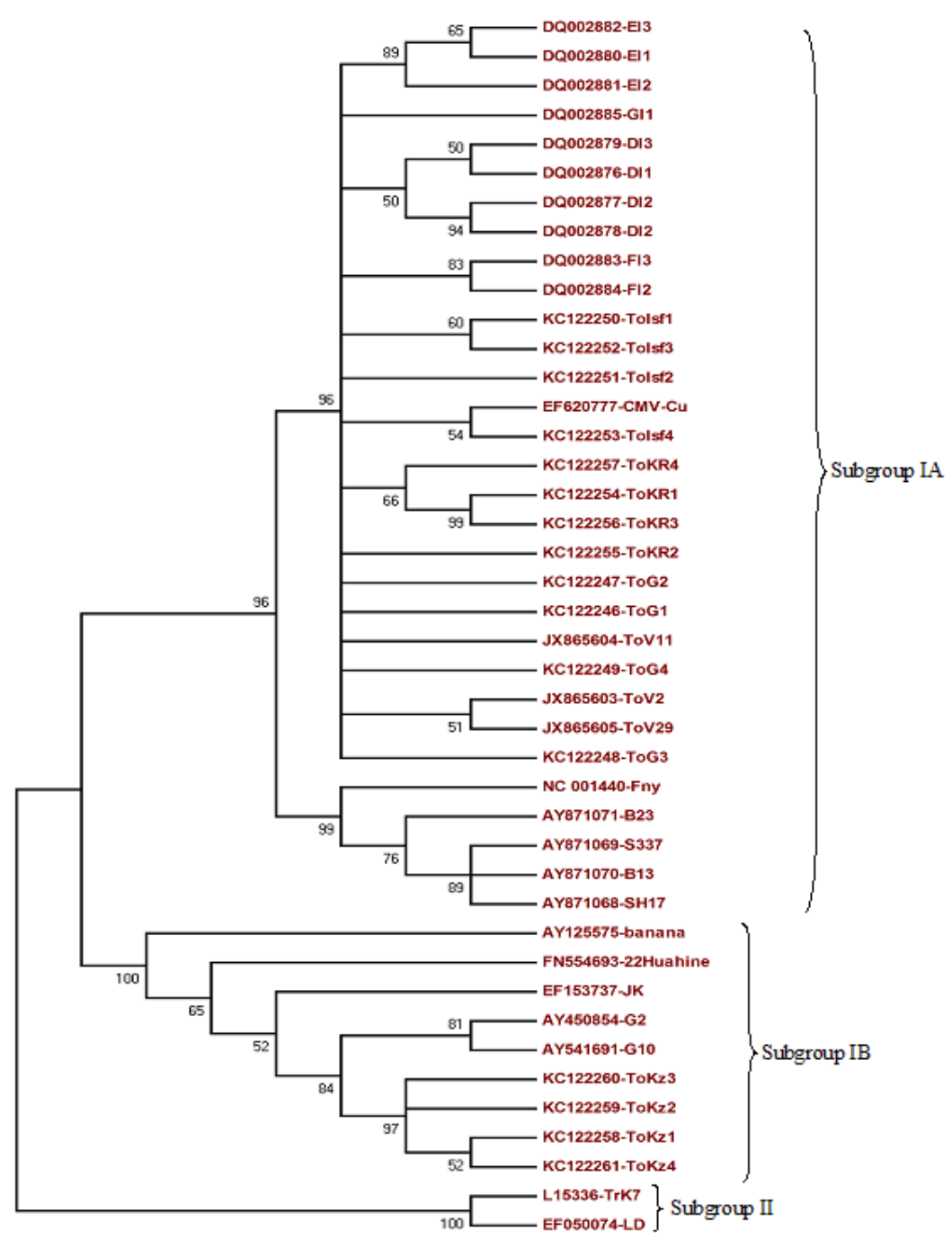

Bootstrap values (1000 replicates) are given at the branch nodes. Branches corresponding to partitions reproduced in less than $50 \%$ of bootstrap replicates are collapsed.

\section{Acknowledgements}

This study was supported by Plant Virus Research Department of Iranian Research Institute of Plant Protection (IRIPP). We would like to thank anonymous reviewers for their helpful comments and recommendations. This study was part of the M.S. thesis of the first author.

\section{Authors' Contribution}

Shirin Farzadfar and the authors have conducted the study.

\section{Financial Disclosure}

There is not any financial interest.

\section{Funding/ Support}

Financial support of IRIPP and Sabzevar branch Islamic Azad University is acknowledged.

\section{References}

1. García-Arenal F, Palukaitis P, Editors-in-Chief: BWJMahy, M. H. V. van Regenmortel . Cucumber Mosaic Virus. In: García-Arenal F, Palukaitis P, Editors-in-Chief: BWJMahy, M. H. V. van Regenmortel , editors.Encyclopedia of Virology (Third Edition).Oxford: Academic Press; 2008. p. 614-19

2. Bujarski J, Figlerowicz M, Gallitelli D, Roossinck MJ, Scott SW, King AMQ, Adams MJ, Carestens EB, Lefkowitz EJ. Family Bromoviridae. In: Bujarski J, Figlerowicz M, Gallitelli D, Roossinck MJ, Scott SW, King AMQ, Adams MJ, Carestens EB, Lefkowitz EJ, editors.Virus Taxonomy Classification and Nomenclatureof Vi- 
ruses. Ninth Report of The International Committee on Taxonomy of Viruses.San Diego: Elsevier; 2012. p. 965-976

3. Palukaitis P, Garcia-Arenal F. Cucumoviruses. Adv Virus Res. 2003;62:241-323

4. Palukaitis P, Roossinck MJ, Dietzgen RG, Francki RI. Cucumber mosaic virus. Adv Virus Res. 1992;41:281-348

5. Crescenzi A, Barbarossa L, Gallitelli D, Martelli GP. Cucumber mosaic cucumovirus populations in Italy under natural epidemic conditions and after a satellite-mediated protection test. Plant Dis. 1993;77:28-33

6. Roossinck MJ. Evolutionary history of Cucumber mosaic virus deduced by phylogenetic analyses. J Virol. 2002;76(7):3382-7

7. Sclavounos AP, Voloudakis AE, Arabatzis Ch, Kyriakopoulou PE. A Severe Hellenic CMV Tomato Isolate: Symptom Variability in Tobacco, Characterization and Discrimination of Variants. Europ J Plant Pathol. 2006;115(2):163-72

8. Chen S, Gu H, Wang X, Chen J, Zhu W. Multiplex RT-PCR detection of Cucumber mosaic virus subgroups and Tobamoviruses infecting Tomato using $18 \mathrm{~S}$ rRNA as an internal control. Acta Biochim Biophys Sin (Shanghai). 2011;43(6):465-71

9. Hosseinzadeh H, Nasrollanejad S, Khateri H. First report of cucumber mosaic virus subgroups $i$ and ii on soybean, pea, and eggplant in iran. Acta Virol. 2012;56(2):145-8

10. Golnaz N, Jafarpour B, Rastegar MF, Sabokkhiz MA. Detection of Cucumber mosaic virus and typing using serological and molecular methods in Razavi Khorasan Province. PakJ Biol Sci. 2009;12(8):657-9

11. Sokhandan Bashir N, Nematollahi S, Torabi E. Cucumber mosaic virus subgroup IA frequently occurs in the northwest Iran. Acto Virol. 2008;52(4):237-42

12. Rasoulpour R, Izadpanah K. Properties and taxonomic position of hoary cress strain of Cucumber mosaic virus. J Plant Path 2008;90(1):97-102

13. Bashir NS, Kalhor MR, Zarghani SN. Detection, differentiation and phylogenetic analysis of cucumber mosaic virus isolates from cucurbits in the northwest region of Iran. Virus Genes. 2006;32(3):277-88

14. Clark MF, Adams AN. Characteristics of the microplate method of enzyme-linked immunosorbent assay for the detection of plant viruses. J Gen Virol. 1977;34(3):475-83

15. Larkin MA, Blackshields G, Brown NP, Chenna R, McGettigan PA McWilliam $\mathrm{H}$, et al. Clustal $\mathrm{W}$ and Clustal $\mathrm{X}$ version 2.0. Bioinformatics. 2007;23(21):2947-8

16. Weiller GF. Phylogenetic profiles: a graphical method for detecting genetic recombinations in homologous sequences. Mol Biol Evol. 1998;15(3):326-35

17. Martin DP, Lemey P, Lott M, Moulton V, Posada D, Lefeuvre P. RDP3: a flexible and fast computer program for analyzing recombination. Bioinformatics. 2010;26(19):2462-3

18. Tamura K, Dudley J, Nei M, Kumar S. MEGA4: Molecular Evolutionary Genetics Analysis (MEGA) software version 4.0. Mol Biol Evol. 2007;24(8):1596-9

19. Swofford DL. Phylogenetic Analysis Using Parsimony. 2001.

20. Page RD. TreeView: an application to display phylogenetic trees on personal computers. Comput Appl Biosci. 1996;12(4):357-8

21. Kimura M. A simple method for estimating evolutionary rates of base substitutions through comparative studies of nucleotide sequences. J Mol Evol.1980;16(2):111-20

22. Dayhoff MO, Barker WC, Hunt LT. Establishing homologies in protein sequences. Methods Enzymol.1983;91:524-45

23. Owen J, Palukaitis P. Characterization of cucumber mosaic virus. I. Molecular heterogeneity mapping of RNA 3 in eight CMV strains. Virology. 1988;166(2):495-502

24. Farreyrol K, Grisoni M, Pearson M, Richard A, Cohen D, Beck D. Genetic diversity of Cucumber mosaic virus infecting vanilla in French Polynesia and Réunion Island. Austral Plant Pathol. 2010;39(2):132-40

25. Salanki K, Thole V, Balazs E, Burgyan J. Complete nucleotide sequence of the RNA 3 from subgroup II of cucumber mosaic virus (CMV) strain: Trk7. Virus Res. 1994;31(3):379-84 